\title{
Challenges and Recommendations for Improving Chemistry Education and Teaching in the Republic of North Macedonia
}

Marina Stojanovska ${ }^{\star 1}$, Ivanka Mijić ${ }^{2}$ AndVladimir M. PetrušEvski ${ }^{3}$

$\approx$ The study aims to present the development of education in North Macedonia from the country's independence to the present day, as documented in several national reports and other official documents. The focus is on development and changes in chemistry education throughout the years of primary, secondary and higher education. Particular attention is devoted to the introduction of the new curricula of natural sciences courses in primary education, which is an adapted curricula of the Cambridge International Examinations, and the use of information and communication technology in increasing the efficiency of the education system. Despite numerous reforms over the years, the country is still faced with various challenges and issues regarding chemistry teaching. Investment in education is constantly decreasing and no notable improvements in conditions for teaching chemistry are being made. Recommendations are made regarding the need for appropriately educated, qualified and motivated teaching staff, well-equipped laboratories and teaching resources, continuous professional development of teachers, mutual cooperation of all stakeholders in the educational process, and continuous support from the authorities and policy makers for gifted pupils and chemistry teachers at all levels.

Keywords: chemistry teaching, curricula, education reforms, natural sciences

$1 \quad{ }^{*}$ Corresponding Author. Faculty of Natural Sciences and Mathematics, Ss. Cyril and Methodius University, Skopje; mmonkovic@yahoo.com.

2 Bureau for Development of Education, Ministry of Education and Science, North Macedonia.

3 Faculty of Natural Sciences and Mathematics, Ss. Cyril and Methodius University, Skopje. 


\section{Izzivi in priporočila za izboljšanje kemijskega izobraževanja in poučevanja $v$ Republiki Severna Makedonija}

Marina Stojanovska, Ivanka Mijić in Vladimir M. Petruševski

$\propto$ Namen prispevka je predstaviti razvoj izobraževanja v Severni Makedoniji od osamosvojitve države do današnjega dne na podlagi številnih nacionalnih poročil in drugih uradnih dokumentov. Poudarek je na razvoju in spremembah v kemijskem izobraževanju v osnovnem, srednjem in $\mathrm{v}$ visokošolskem izobraževanju. Posebna pozornost je namenjena uvedbi novega učnega načrta za poučevanje naravoslovnih predmetov v osnovni šoli, ki je prilagojen učni načrt Cambridge International Examinations, in uporabi informacijsko-komunikacijske tehnologije z namenom povečanja učinkovitosti izobraževalnega sistema. Kljub številnim reformam v zadnjih letih se država še vedno spoprijema s številnimi izzivi in z vprašanji, povezanimi s poučevanjem kemije. Vlaganje $\mathrm{v}$ izobraževanje se nenehno zmanjšuje in ni izvedenih nobenih vidnih izboljšav v pogojih za poučevanje kemije. Oblikovana so priporočila glede na potrebe po primerno izobraženih, usposobljenih in motiviranih učiteljih, dobro opremljenih laboratorijih in virih za poučevanje, programih strokovnega izpopolnjevanja učiteljev, skupno sodelovanje vseh deležnikov v izobraževalnem procesu ter nenehno podporo avtoritet in odločevalcev za nadarjene učence in učitelje kemije na vseh ravneh.

Ključne besede: poučevanje kemije, kurikulum, reforme na področju izobraževanja, naravoslovje 


\section{Introduction}

Quality education and teaching is a prerequisite for the successful formation of pupils' knowledge. Therefore, different ways of improving the quality of education and teaching are constantly sought. A number of measures are taken to improve the quality of teaching and the overall development of the educational process in schools: improvement of the curriculum (Metz, 1997), continuous professional development of teaching staff through in-service education, training and advisory work (Watson, Steele, Vozzo, \& Aubusson, 2007; Wilson, 2000), introducing information technology in teaching (Ardac \& Akaygun, 2004; Barbour \& Reeves, 2009; Carvalho-Knighton \& Keen-Rocha, 2007), improving textbooks and other literature, improving working conditions and providing teaching and learning resources and other equipment (Vosniadou, Ioannides, Dimitrakopoulou, \& Papademetriou, 2001), extending the duration of regular institutional education, as well as empowering pupils and developing self-education habits (Demirdogen \& Cakmakci, 2014). Certainly, the teacher has a key role in overall educational work, especially in the planning, organisation and realisation of teaching, and thus in the process of forming conceptual, quality knowledge among pupils. This can be achieved through the teacher's professional preparedness and competences (Watson et al., 2007), the application of adequate methods, forms and techniques of work, the teacher's ability to teach and transfer knowledge, as well as by encouraging interactive pupil collaboration in thinking and in understanding learning and applying the acquired knowledge to solving problems in specific situations (Tytler, 2002).

The education system in North Macedonia acknowledges the need for and importance of $21^{\text {st }}$ century skills within the context of science education, in order for pupils to be adequately prepared to participate in and contribute to today's society. Science education is therefore of tremendous importance for the country.

The aim of this study is to present the development of chemistry curricula in primary (6-14 years old), secondary (15-18 years old) and higher education (18+ years old) in North Macedonia throughout the years from its independence to the present day. Particular attention is devoted to the introduction of the new curricula of natural sciences and chemistry in primary education, which is an adapted curricula of the Cambridge International Examinations (CIE). Challenges and recommendations for improving chemistry education and teaching are ascertained. 


\section{General Overview of Education in North Macedonia}

North Macedonia is trying to develop and implement the measures mentioned above for improving the quality of education and teaching in schools. The education system in North Macedonia is structured through different levels depending on the age, necessities and affinities of the pupils. The first level is preschool, which is optional, while primary education lasts for nine years. There is also primary music and ballet education, as well as primary education for pupils with special educational needs. The International Baccalaureate programme has been implemented in several primary schools, as well. Secondary education includes gymnasium (grammar school), vocational education, sports gymnasium, sports academy, secondary music and ballet education, and secondary art education. All of these are four-year models, although vocational education can last two, three or four years. Since 2007, secondary education has been compulsory for every citizen under equal conditions, as determined by the Law on Secondary Education (2017). Adult education is also available. Education at university level is the highest level in the education system.

Since primary education in Macedonia remained the same for more than a decade after the country's independence, it seemed appropriate to create and implement a new concept for primary education. The main goal was to improve the content, organisation and quality of education. According to the National Programme for the Development of Education in Macedonia for 2005-2015 (Geramitčioski et al., 2004), a new concept for nine-year primary education was developed and introduced in 2007 (Concept for Nine-Year, 2007). In the development of the primary education system in Macedonia, it was deemed appropriate to learn from the Slovenian experience, in view of the latter's long tradition and experience, as well as the similar principles in the development of education shared by Macedonia and Slovenia. Many research projects have been undertaken aimed at the introduction of interactive teaching and active learning in schools, based on the experience from descriptive assessment and from the introduction of the national assessment of pupils in our country. There are compulsory and elective courses in the teaching process, which create opportunities for individualised approaches in certain courses. The compulsory courses in primary schools are from the area of language and literature, social sciences, mathematics, natural sciences, technical education, technology, information technology, arts, sport and health education. Moreover, the school has the responsibility to plan and organise additional lessons both for pupils who progress at a slower pace and for those who achieve outstanding results and have shown special skills and talents in certain courses. 
During the past years, the concept for nine-year primary education has been continuously improving in various segments. Therefore, new courses and syllabi have been introduced or revised according to the needs of pupils and modern educational trends. One of the most prominent reforms is the introduction of the Cambridge International Examinations curricula for mathematics and science courses.

Secondary schools are organised as public or private schools, and the educational process is carried out according to the respective curricula and syllabi adopted by the Minister of Education and Science on the proposal of the Bureau for the Development of Education - BRO (https://www.bro.gov.mk/) and the Vocational Education and Training Centre - CSOO (http://csoo.edu. $\mathrm{mk} /$ ), in accordance with the Law on Secondary Education. Secondary education in Macedonia underwent major changes in the period after 1980. With the introduction of the Concept for Specialised Secondary Education, gymnasium programmes were replaced with specifically tailored curricula for cultural enlightenment and natural science and mathematics disciplines. This concept was applied until 1990, when, due to extensive criticism, amendments were introduced to the Law on Secondary Education and immediate preparations started for returning the curricula and syllabi for the gymnasium, the implementation of which commenced in the 1991/92 school year.

After the break-up of Yugoslavia, a system of three- and four-year secondary vocational education and gymnasium education remained. There were three types of gymnasium education: general gymnasium, natural sciences and mathematics gymnasium, and linguistic gymnasium. In the 2001/02 school year, the gymnasium curriculum was reformed (Analysis of Gymnasium Education, 2008; Đeladini, Stojanovski, Mitrevska, \& Andreevski, 2004), and it has not been changed to this day.

Since 2001, there have been three gymnasium areas: natural sciences and mathematics - combination A and combination B (combination B is chosen by pupils who plan to study at chemistry or biology-related faculties), linguisticsarts - combination A and combination B, and social-humanities - combination A and combination B. The gymnasium curriculum is structured by three types of courses: compulsory courses, optional courses and project activities. Compulsory courses represent the core knowledge for all pupils and are a prerequisite for providing a general education standard. The number of such courses gradually decreases from the first (10-11) to the fourth year (5-6). Optional courses differentiate pupils according to their orientation towards certain areas and combinations. These courses are aimed at deepening and expanding the knowledge of pupils and are represented by two or three school hours per week 
each, from the second to the fourth year. Obviously, each area contains two combinations of optional courses, on the basis of which each pupil is prepared for appropriate studies. Project activities are selected by the pupils.

Three-year vocational education was reformed in the 20oos, according to the PHARE programme (Poland and Hungary: Assistance for Restructuring their Economies), followed by reforms for certain profiles in 2013. In 2017, coordinated by the CSOO, two-year and three-year vocational education was reformed and, in 2018, four-year vocational education was also reformed. A methodology for the development of modular curricula based on competences has recently been introduced, in some cases related to labour market demands. This was initially a pilot in three vocational disciplines, but continued in the 2019/20 school year in all vocational disciplines, resulting in new chemistry curricula being prepared for certain profiles/qualifications.

A more significant reform (Ministry of Education and Science, 2018) is the introduction of the concept of dual education in secondary vocational schools, following the German model, which will hopefully enable an easier transition of pupils from the educational process to work. Dual vocational education involves greater cooperation between schools and the business sector, and includes more practice for pupils, under the mentorship of employees in companies. In this way, pupils will acquire the necessary competencies and skills to hopefully enable them to work immediately after completing their education.

It was initially planned to introduce new curricula and syllabi in 2017/18 for mathematics, biology, chemistry and physics, based on adapted curricula of the CIE, in gymnasium education and vocational three- and four-year education, as a continuation of the curricula in primary education. However, in 2017, it was decided to postpone the implementation of these programmes for secondary education (Trajkovska et al., 2019). It is believed that long-term solutions for secondary education will emerge from the Strategic Plan on Education 2018-2025 and the Action Plan (2018), on the basis of which a new concept for secondary education will be developed, educational standards will be defined, and the projected solutions will be implemented in schools.

The roots of higher education in Macedonia stretch back seven decades. In 1946, the first faculty using the Macedonian language was founded, the Faculty of Philosophy, with two departments: (1) Natural Sciences and Mathematics, and (2) Social Sciences and Humanities. In subsequent years, several more faculties emerged, so in 1949 the first Macedonian university, the Ss. Cyril and Methodius University (UKIM), was founded (Manevska \& Fotinovska, 2019).

The University currently represents a functional community of 23 faculties, 5 research institutes and 12 various associate members. Its activities are 
stipulated by the Law on Higher Education and the Statute of the University. The UKIM develops study programmes in all scientific fields: natural sciences and mathematics, engineering sciences, medical sciences and health, biotechnical sciences, social sciences, humanities and arts. In addition to research at the faculties, research work is also carried out in independent research institutes, which form an integral part of the university.

An illustration of the UKIM today through figures is as follows: over 60,000 students from North Macedonia enrolled in undergraduate and master's studies, as well as over 700 foreign students. The number of students enrolled in undergraduate studies at the Faculty of Natural Sciences and Mathematics in the current year is 305 ( 48 at the Institute of Chemistry) from a total of 5,614 at the UKIM. Doctoral studies are realised within the Doctoral School (2008), with a total of 655 students. Over 3,10o teaching, research, associate and administrative staff participate in delivering the teaching and scientific process at the faculties and institutes. The University has produced around 150,000 graduated high-level professional staff (with a bachelor's degree), including 10,000 graduates with an MSc degree and around 4,00o with a PhD.

Undergraduate studies last six or eight semesters (180 or 240 ECTS points). Upon graduation, the student may be obliged to submit a graduation thesis, but not in all cases (depending on the details of the specific curriculum). Master's studies last for two or four semesters (60 or 120 ECTS points). A master's thesis is a compulsory part of completing the studies at all faculties. Doctoral studies last six semesters (180 ECTS points) and are organised by the Doctoral School, at the university level. Two generic courses and three seminars are compulsory, together with a large number of elective courses. This cycle is completed by the defence of a $\mathrm{PhD}$ thesis.

\section{Chemistry Curricula in Primary Education}

The focus of the primary school teaching process is the BRO approved curriculum (Table 1) and syllabi (Tables 2-4) for natural sciences courses, with a particular emphasis on chemistry (Stojanovski, Andreevski, \& Spasovski, 1995). In the 2014/15 academic year, BRO introduced new curricula for mathematics and natural sciences courses, based on adapted CIE curricula. With this reform, the science course is differentiated as a separate subject from the first to third grade and, according to the curricula, the scope of natural sciences content is broader than in previous curricula. The programme is characterised by scientific investigation intended to encourage pupils to focus on problem-solving skills and to develop a scientific point of view, thus helping them to solve problems in 
everyday life. In this way, pupils have an opportunity to acquire broader, deeper and more significant knowledge in the field of natural sciences, as well as to develop practical skills for research. Furthermore, content domains, cognitive domains and practices in the curricula are comparable to international standards of learning, such as those set in TIMSS (Centurino \& Jones, 2017).

Table 1

Curriculum overview of natural sciences courses

\begin{tabular}{|c|c|c|c|c|c|c|c|c|c|}
\hline \multirow{2}{*}{ Course } & \multicolumn{9}{|c|}{ Number of classes per week } \\
\hline & $1^{1 s t}$ & $2^{\text {nd }}$ & $3^{\text {rd }}$ & $4^{\text {th }}$ & $5^{\text {th }}$ & $6^{\text {th }}$ & $7^{\text {th }}$ & $8^{\text {th }}$ & $9^{\text {th }}$ \\
\hline $\begin{array}{l}\text { Introduction to Nature and } \\
\text { Society }\end{array}$ & $2^{*}$ & $2^{*}$ & $3^{*}$ & & & & & & \\
\hline Introduction to Nature & & & & $2^{*}$ & & & & & \\
\hline Introduction to Society & & & & $2^{*}$ & & & & & \\
\hline $\begin{array}{l}\text { Introduction to the } \\
\text { Environment }\end{array}$ & $2^{* *}$ & $3^{* *}$ & $3^{* *}$ & & & & & & \\
\hline Nature & & & & $2^{* *}$ & & & & & \\
\hline Science & & & & & $2^{* *}$ & & & & \\
\hline Science and Engineering & & & & & & $3^{* *}$ & & & \\
\hline Science (Cambridge) & $2^{* * *}$ & $2^{* * *}$ & $2^{* * *}$ & $2^{* * *}$ & $2^{* * *}$ & $2^{* * *}$ & & & \\
\hline Biology & & & & & $1^{*}$ & $2^{*}$ & $\begin{array}{l}2^{*} \\
2^{* *}\end{array}$ & $\begin{array}{l}2^{*} \\
2^{* *}\end{array}$ & $2^{* *}$ \\
\hline $\begin{array}{l}\text { Biology } \\
\text { (Cambridge) }\end{array}$ & & & & & & & $2^{* * *}$ & $2^{* * *}$ & $2^{* * *}$ \\
\hline Chemistry & & & & & & & $2^{*}$ & $\begin{array}{l}2^{*} \\
2^{* *}\end{array}$ & $2^{* *}$ \\
\hline $\begin{array}{l}\text { Chemistry } \\
\text { (Cambridge) }\end{array}$ & & & & & & & & $2^{* * *}$ & $2^{* * *}$ \\
\hline Physics & & & & & & & $2^{*}$ & $\begin{array}{l}3^{*} \\
2^{* *}\end{array}$ & $2^{* *}$ \\
\hline $\begin{array}{l}\text { Physics } \\
\text { (Cambridge) }\end{array}$ & & & & & & & & $2^{* * *}$ & $2^{* * *}$ \\
\hline
\end{tabular}

Note. * 1994-2007 curriculum; ** 2007-2014 curriculum; *** 2014-2019 curriculum (2016-2019 - Biology, Chemistry and Physics). 
Table 2

Thematic overview of 2007-2014 science-related syllabi

\begin{tabular}{|c|c|c|}
\hline \multicolumn{3}{|c|}{ Introduction to the Environment } \\
\hline $1^{\text {st }}$ grade & $2^{\text {nd }}$ grade & $3^{\text {rd }}$ grade \\
\hline $\begin{array}{l}\text { Me and Others } \\
\text { My School } \\
\text { My Home } \\
\text { The Place Where I Live } \\
\text { I Am Part of Nature } \\
\text { Traffic }\end{array}$ & $\begin{array}{l}\text { Me with Others } \\
\text { Life and Work at School } \\
\text { My Place } \\
\text { My Home } \\
\text { I Am Part of Nature } \\
\text { I'm Exploring } \\
\text { Traffic }\end{array}$ & $\begin{array}{l}\text { Me with Others and Others with Me } \\
\text { School and Knowledge } \\
\text { Family Relationships } \\
\text { My Birthplace } \\
\text { Exploring Nature } \\
\text { Environmental Features } \\
\text { Orientation in Time and Space } \\
\text { Traffic }\end{array}$ \\
\hline Nature & Science & Science and Engineering \\
\hline $4^{\text {th }}$ grade & $5^{\text {th }}$ grade & $6^{\text {th }}$ grade \\
\hline $\begin{array}{l}\text { Nature } \\
\text { Materials and Energy in } \\
\text { Nature } \\
\text { Planet Earth is a Variable } \\
\text { System } \\
\text { The Living World in Nature } \\
\text { Ecology }\end{array}$ & $\begin{array}{l}\text { Nature and Natural Sciences } \\
\text { Planet Earth } \\
\text { Matter and Energy on Earth } \\
\text { Earth's Orientation } \\
\text { Ecology and Diversity of } \\
\text { Wildlife }\end{array}$ & $\begin{array}{l}\text { Planet Earth in Space } \\
\text { The Earth is a Dynamic System } \\
\text { Features of Wildlife } \\
\text { Ecology } \\
\text { Natural Sciences in Everyday Life }\end{array}$ \\
\hline
\end{tabular}

Table 3

Thematic overview of 2014-2019 science syllabi (Cambridge)

\begin{tabular}{lll}
\hline $\mathbf{1}^{\text {st }}$ grade & $\mathbf{2}^{\text {nd }}$ grade & $\mathbf{3}^{\text {rd }}$ grade \\
\hline Us & Light and Darkness & Life Processes \\
What is it made of? & Electricity & Materials \\
Living and Growing & Change of Materials & Plants that Blossom \\
Push and Pull & Investigating Rocks & Introduction to Forces \\
Making Sounds & The Universe & Senses \\
Plant Cultivation & Plants and Animals around & Keeping Up Good Health \\
& Us & \\
\hline $\mathbf{4}^{\text {th }}$ grade & $\mathbf{5}^{\text {th }}$ grade & $\mathbf{6}^{\text {th }}$ grade \\
\hline Habitats & Evaporation and Condensa- & Reversible and Irreversible \\
Solid Matter, Liquids and & tion & Changes \\
Gases & How We See Things around & Organs and Systems in the Human \\
Making Circuits & Us & Body \\
How do magnets work? & Earth Movement & Conductors and Insulators \\
Skeleton and Muscles & Shadows & Environmental Care \\
Sound & The Life Cycle of Flower & Growing \\
& Plants & Food Chains \\
& Investigating Plant Growth & Forces and Movement \\
\hline
\end{tabular}

The chemistry curricula were implemented in the 2016/17 school year for both $8^{\text {th }}$ and $9^{\text {th }}$ grade pupils. The learning content for chemistry (as well as for biology and physics) were reduced compared to that covered by the previous syllabi, but the number of classes for pupils' research activities was 
increased, thus fostering experimenting in the learning process. For this generation of nine-graders, some topics were repeated from the previous year, others were missing and few were added, as pupils were starting the programme for the first time and had studied according to another curriculum the previous year. Thus, for example, atomic structure and periodic table concepts were present both in the $8^{\text {th }}$ grade syllabus of the old programme and in the $9^{\text {th }}$ grade syllabus of the new programme. This step caused numerous reactions, as the curricula were adapted over a very short period of time and without discussion with stakeholders.

Table 4

Thematic overview of 2009-2019 chemistry syllabi (with the recommended number of hours)

\begin{tabular}{|c|c|}
\hline $8^{\text {th }}$ grade & $9^{\text {th }}$ grade \\
\hline \multicolumn{2}{|l|}{ Chemistry } \\
\hline $\begin{array}{l}\text { Chemistry as a Part of Science (10) } \\
\text { Substances (26) } \\
\text { Atomic Structure, the Periodic Table of } \\
\text { Elements and Chemical Bonding (16) } \\
\text { Oxides (5) } \\
\text { Acids (4) } \\
\text { Hydroxides (4) } \\
\text { Salts (7) }\end{array}$ & $\begin{array}{l}\text { Oxidation and Reduction (6) } \\
\text { Simple Chemical Calculations (8) } \\
\text { Metals and Non-Metals (14) } \\
\text { Hydrocarbons (16) } \\
\text { Organic Compounds Containing Oxygen (10) } \\
\text { Biocompounds (14) } \\
\text { (Additional } 4 \text { hours, where necessary) }\end{array}$ \\
\hline \multicolumn{2}{|l|}{ Chemistry (Cambridge) } \\
\hline $\begin{array}{l}\text { States of Matter (5) } \\
\text { Metals and Non-Metals (11) } \\
\text { Elementary Substances, Compounds } \\
\text { and Mixtures (16) } \\
\text { Chemical Reactions (31) } \\
\text { Introduction to Organic Chemistry (9) }\end{array}$ & $\begin{array}{l}\text { Atomic Structure and the Periodic Table of Elements (13) } \\
\text { Valences and Formulas (5) } \\
\text { Rate of Reaction (14) } \\
\text { lonic Bonding and Balancing Chemical Equations (7) } \\
\text { Reactivity Series (12) } \\
\text { Making Salts (10) } \\
\text { Exothermic and Endothermic Reactions (11) }\end{array}$ \\
\hline
\end{tabular}

By comparing the chemistry syllabi before and after 2016 (Table 4), it can be noticed that the old syllabus differs from that of the "Cambridge" programme, although there are certain topics in common. Thus, organic chemistry topics in the new curriculum are very limited. Only the first four representatives of the alkanes are mentioned, without going more deeply into nomenclature, isomerism and reactions. Other classes of organic compounds and bio compounds are not introduced at all. In addition, no chemistry calculations are included in the current chemistry syllabi. On the other hand, the Reactivity Series topic is present in current syllabi, thus providing a better approach to gaining preliminary knowledge about oxidation-reduction reactions. The Rate of Reaction topic, which is a novel one, correlates with the secondary education 
chemistry syllabus, so it eases further learning. These two topics also focus on experimenting, thus ensuring the acquisition of sound long-lasting knowledge instead of just theoretical and unessential knowledge.

\section{Chemistry Curricula in Secondary Education}

From 1991 to 2001, chemistry was taught for two school hours per week in all four years in the general and linguistic gymnasium. In the natural sciences and mathematics gymnasium, there were three school hours per week in the first and third year and two school hours per week in the second and fourth years. One school hour per week (out of a total of three) was planned for experimental work. Since 2001, chemistry teaching in gymnasium education has been carried out for two school hours per week in the first, second and third year, as a compulsory course for all areas. It is represented by three school hours per week only for the natural sciences and mathematics gymnasium area, combination B in the final year. With the reform in 2001, there are no more classes for experimental work in gymnasium education. A thematic overview of the chemistry courses in gymnasium education is given in Table 5.

Table 5

Overview of the 1991-2019 chemistry syllabus in the gymnasium (with recommended number of hours)

\begin{tabular}{|c|c|}
\hline $1991-2001$ & 2001-2019 \\
\hline \multicolumn{2}{|c|}{ I } \\
\hline $\begin{array}{l}\text { Introduction (3) } \\
\text { Chemical Measurements (5) } \\
\text { Chemical Symbols, Formulae and Equations (5) } \\
\text { Simple Chemical Calculations (5) } \\
\text { Structure of the Atom and the Periodic Table (7) } \\
\text { Molecules, Ions and Crystals (7) } \\
\text { Classification of Chemical Compounds (4) } \\
\text { Chemical Processes (10) } \\
\text { Disperse Systems (6) } \\
\text { Electrolytes (4) } \\
\text { Proton Transfer Reactions (5) } \\
\text { Oxidation-Reduction Reactions (6) } \\
\text { Chemical Reactions and Electricity (3) } \\
\text { Chemical Information (2) }\end{array}$ & $\begin{array}{l}\text { Introduction to Chemistry (18) } \\
\text { Structure of Matter (28) } \\
\text { Inorganic Compounds (10) } \\
\text { Disperse Systems (16) }\end{array}$ \\
\hline
\end{tabular}




\begin{tabular}{ll}
\hline 1991-2001 & 2001-2019 \\
\hline & II \\
Introduction (1) & Introduction to Chemistry Processes (9) \\
Structure of Organic Molecules (7) & Chemical Kinetics (7) \\
Hydrocarbons (27) & Chemical Equilibrium (6) \\
Haloalkanes (3) & Proton Transfer Reactions (14) \\
Alcohols (6) & Oxidation-Reduction Reactions (8) \\
Phenols (3) & Electrochemical Processes (9) \\
Ethers (2) & Chemical Reactions in Industry (19) \\
Aldehydes and Ketones (8) & \\
Carboxylic Acids (9) & \\
Nitro-Compounds and Amines (4) & \\
Heterocyclic Compounds (2) & \\
\hline
\end{tabular}

III

Structure of Matter (22)

Introduction to Inorganic Chemistry (1)

$s$-elements (11)

p-elements (26)

$d$-elements (10)

$f$-elements (2)

Introduction to Organic Chemistry (8)

Hydrocarbons (28)

Organic Compounds of Oxygen and Nitrogen

(30)

Reactivity and Types of Organic Reactions (6)

IV

Chemical Reactions (21)

Chemistry in Us (28)

Learning through Investigation (10)

Chemistry around Us (17)

Biochemistry Basics (26)

The Elements and their Compounds (36)

Stoichiometry (21)

(Additional 6 hours, where necessary)

Chemistry is studied as a compulsory and/or optional course for many educational profiles in vocational education, usually for two school hours per week, except in the chemical-technology discipline, where various chemistry courses are offered.

\section{Chemistry Curricula in Higher Education}

The "centre of chemistry events" within the university is located at the Institute of Chemistry, which is part of the Faculty of Natural Sciences and Mathematics. All fundamental chemistry courses are taught at the Institute. More specialised courses, such as Biochemistry, Spectroscopy, Radiochemistry, and Instrumental Methods in Chemistry, are also taught. There are several disciplines around which the studies are organised: Applied Chemistry, Analytical Biochemistry, Environmental Chemistry, and Educational Chemistry (see Table 6). All chemistry studies at the undergraduate level last for eight semesters. A BSc graduate in chemistry can work in industry and in various laboratories, while Graduate Professors of Chemistry (BSc) are qualified to work in all primary and secondary schools. Master's studies last two semesters and are composed of several compulsory courses (Methodology of Research, Computers 
in Chemistry, etc.) as well as a number of elective courses. Doctoral studies are integrated within the university's Doctoral School.

Table 6

Detailed curriculum of educational chemistry undergraduate studies

\begin{tabular}{|c|c|c|c|c|}
\hline Course & Lectures & $\begin{array}{l}\text { Problem- } \\
\text { Solving }\end{array}$ & $\begin{array}{c}\text { Experimental } \\
\text { Work }\end{array}$ & $\begin{array}{l}\text { ECTS } \\
\text { Points }\end{array}$ \\
\hline \multicolumn{5}{|l|}{ Semester I } \\
\hline General Chemistry - A-level & 4 & 2 & 3 & 10 \\
\hline Mathematics I & 4 & 3 & 0 & 8 \\
\hline Psychology & 2 & 2 & 0 & 4 \\
\hline Macedonian Language & 2 & 2 & 0 & 4 \\
\hline Safety and Protocol in the Laboratory & 2 & 0 & 2 & 2 \\
\hline Sport and Health - UKIM & & & & 2 \\
\hline \multicolumn{5}{|l|}{ Semester II } \\
\hline Inorganic Chemistry - A-level & 4 & 2 & 3 & 8 \\
\hline Mathematics II & 4 & 3 & 0 & 8 \\
\hline General Physics - B-level & 4 & 2 & 2 & 8 \\
\hline Pedagogy & 2 & 2 & 0 & 4 \\
\hline Foreign Language - UKIM & 0 & 4 & 0 & 2 \\
\hline \multicolumn{5}{|l|}{ Semester III } \\
\hline Inorganic Chemistry - selected topics & 3 & 1 & 3 & 6 \\
\hline Organic Chemistry I & 4 & 1 & 5 & 10 \\
\hline Analytical Chemistry I - B-level & 2 & 1 & 4 & 6 \\
\hline Communication Skills & 2 & 1 & 0 & 2 \\
\hline History of Chemistry & 2 & 1 & 0 & 4 \\
\hline Elective Course - UKIM & & & & 2 \\
\hline \multicolumn{5}{|l|}{ Semester IV } \\
\hline Organic Chemistry II - B-level & 3 & 1 & 4 & 8 \\
\hline Physical Chemistry I - B-level & 3 & 0 & 3 & 6 \\
\hline Analytical Chemistry II & 3 & 2 & 4 & 8 \\
\hline Chemistry in Practice & 3 & 1 & 0 & 4 \\
\hline Computers in Chemistry & 2 & 1 & 0 & 4 \\
\hline \multicolumn{5}{|l|}{ Semester V } \\
\hline Biochemistry I - B-level & 3 & 1 & 3 & 8 \\
\hline Physical Chemistry II - B-level & 3 & 0 & 3 & 8 \\
\hline Instrumental Analytical Methods - B-level & 3 & 1 & 3 & 6 \\
\hline Environmental Chemistry & 2 & 0 & 4 & 6 \\
\hline
\end{tabular}




\begin{tabular}{|c|c|c|c|c|}
\hline Course & Lectures & $\begin{array}{l}\text { Problem- } \\
\text { Solving }\end{array}$ & $\begin{array}{l}\text { Experimental } \\
\text { Work }\end{array}$ & $\begin{array}{l}\text { ECTS } \\
\text { Points }\end{array}$ \\
\hline \multicolumn{5}{|l|}{ Semester VI } \\
\hline Physical Chemistry - selected topics & 3 & 1 & 3 & 8 \\
\hline General Methods of Chemistry Teaching & 3 & 2 & 2 & 8 \\
\hline Experimental Organic Chemistry & 2 & 0 & 5 & 6 \\
\hline Biochemistry II & 3 & 0 & 3 & 6 \\
\hline Elective Course - Chemistry & & & & 4 \\
\hline \multicolumn{5}{|l|}{ Semester VII } \\
\hline $\begin{array}{l}\text { Methods of Experimenting in Chemistry } \\
\text { Teaching I }\end{array}$ & 3 & 1 & 5 & 10 \\
\hline Special Methods of Chemistry Teaching & 3 & 2 & 2 & 8 \\
\hline $\begin{array}{l}\text { Modern Technologies in Chemical } \\
\text { Education }\end{array}$ & 2 & 2 & 0 & 4 \\
\hline Elective Course - Chemistry & & & & 4 \\
\hline Elective Course - Chemistry & & & & 4 \\
\hline \multicolumn{5}{|l|}{ Semester VIII } \\
\hline $\begin{array}{l}\text { Methods of Experimenting in Chemistry } \\
\text { Teaching II }\end{array}$ & 3 & 1 & 5 & 10 \\
\hline School Practice & 2 & 4 & 0 & 6 \\
\hline Elective Course - Chemistry & & & & 4 \\
\hline Elective Course - UKIM & & & & 2 \\
\hline Graduation Thesis & 0 & 2 & 6 & 8 \\
\hline
\end{tabular}

Chemistry courses are of fundamental importance for other students, too. Unfortunately, at the Faculty of Technology and Metallurgy, many of the chemistry courses are taught by non-chemists. The situation is similar at the Faculty of Pharmacy. A number of other faculties (Medicine, Dentistry, Veterinary Medicine) deliver chemistry courses for students using experts without specific competencies (experts in other fields, not chemistry). It must be said that this long-term practice is contrary to the Law on Higher Education (2018), both in its present form as well as its previous guises.

In fairness, however, it should be noted that there are other faculties (the Faculty of Forestry, and the Faculty of Agricultural Sciences and Food) where chemistry courses are taught by chemists, in complete accordance with the Law. A few decades ago, a general chemistry course was taught at the Faculty of Civil Engineering. Unfortunately, no chemistry is being taught there today. This course was important, in our opinion, as it gave students at least some insight into the complex processes occurring during the preparation of concrete and similar important materials used in civil engineering.

Finally, it should be mentioned that there are five other public universities 
and some twenty private universities. The State University of Tetovo offers Educational Chemistry and Educational Physics studies, and both primary and secondary school teachers of chemistry and physics are educated there.

\section{Challenges Regarding Science Teaching}

North Macedonia has dealt with numerous reforms over the years, affecting all levels of education. Despite this, the country is still faced with various challenges and issues regarding education overall. There has been an awareness of the poor situation regarding equipment in natural sciences workrooms for a long time (Stojanovski et al., 1995), and the introduction of modern teaching technology in education has not been implemented systematically and is inadequately coordinated. Investment in education is constantly decreasing and no notable improvements in conditions for chemistry teaching are being made.

This is confirmed by the project "One Computer Per Pupil", which was initiated back in 2007 and is a very controversial investment. It has been criticised by the public and educators as so-called "make-up", a bad picture of reality. A lot of equipment was provided (Jašari, 2010), but it turned into a source of problems for school principals and teachers because a sizeable part of the equipment appeared to be missing. There is no official information about the exact price of this global project. Some estimates claim that the project met only 20 percent of the real needs; at least 30 percent of the educational process is supposed to be performed using computers. In short, the project was governed by the goodwill of its architects, but was not realised to the necessary extent. The problems persist.

As mentioned earlier, one of the biggest reforms was the introduction of the CIE curricula for mathematics and natural sciences courses. Regarding chemistry, the curriculum requires a well-equipped laboratory for the successful performance of inquiry-based activities, which is a positive feature of this programme. Unfortunately, the situation is ideal only on paper. In North Macedonia, the equipment in many schools is not at the desired level and not all of the experiments can be performed. Moreover, experiments usually take place in traditional classrooms and are carried out without the help of an assistant. Thus, one of the biggest problems when it comes to chemistry teaching is to equip school workrooms and laboratories (providing they exist!). This is essential for both schools and faculties. Unfortunately, pupils and students are deprived of the most beautiful and most interesting parts of chemistry, the parts that enable them to learn the most and develop their critical and creative thinking, and from which they can acquire the practical skills needed for their 
future life, irrespective of whether or not they choose chemistry for their future profession.

Another problem is the lack of handbooks for pupils and teachers, which are required by the CIE curricula in addition to textbooks. Together with lab equipment and competent teachers, this is the key to the programme's success. In North Macedonia, the application of this curriculum has been reduced because teachers lack appropriate settings and resources, and are forced to improvise to obtain the minimum necessary results. They are often forced to use video experiments and presentations, which can by no means replace the experiment and the teacher's spoken word.

The CIE curricula, as well as the syllabus itself, subsequently provoked many reactions, and there were doubts about their implementation, particularly with regard to the rapid changes in the curricula and the even faster introduction of new (translated) textbooks without consulting all stakeholders. The implementation of such programmes without providing serious prior analyses will unavoidably cause a decrease in the level and quality of the acquired knowledge, and will have long-lasting consequences. This is already reflected in the lack of continuity in the teaching content, as well as the omission of entire thematic units or crucial concepts (such as calculations and organic chemistry concepts). Simply mirroring foreign systems without providing the necessary preconditions for implementation is problematic and counterproductive.

As previously stated, in the first six grades, natural sciences are studied in an integrated form. Unfortunately, the education system in North Macedonia does not prepare teachers for the integrated teaching of natural sciences. In their initial education, teachers of grades 1-4 are not educated for specific teaching methods in biology, chemistry and physics. On the other hand, teachers of grades 5 and 6 are graduates of two-course (biology-chemistry) or singlecourse studies (biology, chemistry, physics). The fact that in-service teachers are not prepared for integrated teaching is confirmed by the teachers themselves. In an article by Spasovska (2017), the author interviews a primary school teacher, who states:

We are not biologists, chemists, or physicists. We need to have a lot of specific knowledge to put it into practice. A two-day training certainly cannot do a lot. Neither do we have equipment and resources to deliver the material to pupils. The number of pupils is too big in the classes to do any research-like activity. (We are not Ready for Cambridge Education, para. 7) 
In recent years, career advancement of teachers has been proposed, and there have been efforts to support the continuous professional development of teachers in key areas such as pupil assessment techniques. However, these efforts are not sustainable and a merit-based career system has not yet been implemented. From 2013 to 2017 , a nationally standardised assessment was conducted in North Macedonia to compare grades given by teachers with pupils' results in standardised assessment, and to rank teachers in terms of objectivity in assessment, with the highest ranked to be rewarded. However, the reward system was never implemented, a lot of pressure was put on teachers, and this kind of assessment was terminated. In North Macedonia, a new national assessment is now planned. If devised well, this assessment could provide useful information to monitor pupils' results in the key stages of their education in relation to national goals.

To date, North Macedonia, via the Ministry of Education and Science $(\mathrm{MON})$, has been involved in three testing cycles of the Programme for International Student Assessment (PISA) of the Organisation for Economic Cooperation and Development (OECD), in 2000, 2015 and 2018. These activities have been implemented by the State Examination Centre (http://matura.gov. $\mathrm{mk} /$ ) and the BRO. The results of the 2000 PISA tests, which were held in 41 countries around the world, ranked Macedonia $38^{\text {th }}$, suggesting that a large percentage of pupils who have completed primary education have not achieved high levels of competence. Such results are a serious indicator of the questionable quality of teaching and highlight the need to introduce systemic changes to increase the level of literacy (Report on the Progress, 2009). At the 2015 PISA testing (OECD, 2019), 15-year-olds showed that they lag nearly four years behind peers from OECD countries. North Macedonia participated in PISA again in 2018 and the results of this assessment are due to be published in December 2019 (European Commission, 2019). The country has also participated in four cycles of TIMSS, in 1999, 2003, 2011 and 2019.

With regard to vocational education, previous reports (Report on the Progress, 2009) state that it does not fully meet the needs of the labour market and does not offer sufficient opportunities for rapid and effective training of pupils for practical occupations. For these reasons, the programmes have been reformed, starting from 2017 (Trajkovska et al., 2019).

\section{Recommendations and Conclusions}

For the continuous development of education, there is a permanent need to take measures to develop appropriate curricula, improve working 
conditions, provide equipment and teaching resources, increase financial support, and improve the care and maintenance of facilities and equipment, as well as other activities in schools. Without lab materials and other resources, quality teaching is not possible, and thus acquiring solid knowledge, work habits and skills becomes a delusion (Vosniadou et al., 2001). It is therefore necessary to provide an annual fund for teaching resources in natural sciences courses. It is also necessary to modernise and maintain schools and student laboratories, as well as sustaining other important activities for the smooth functioning of the teaching process. Insufficient funding and a lack of transparency in the allocation of funds results in most schools not having adequate resources to cover basic costs, let alone to invest in improving the conditions for learning and teaching (OECD, 2019).

In addition to revising curricula for individual courses, a correlation with the curricula of other courses is needed, especially those in mathematics, physics, chemistry and biology. More attention should be paid to this in future reforms. As an example, in the current programme in secondary education, pupils are required to calculate a $\mathrm{pH}$ value, but they have not yet learned logarithms in mathematics. When speaking of correlation, it seems important to note that, although the idea of the curriculum is to provide continuity in studying natural sciences from the $1^{\text {st }}$ to the $9^{\text {th }}$ grade, only biology is present in $7^{\text {th }}$ grade.

As mentioned in the previous section, in-service teachers do not have adequate initial education to teach natural sciences in an integrated form. This is due to the lack of a strategic perspective and the illogical sequence of events. The new science curricula are implemented without appropriate education of the teaching staff and teacher students/future teachers, as well. Furthermore, in North Macedonia, there is an "option" for pedagogical-psychological-methodical post-qualification for graduates. Offering such education as an option reflects a failure to take into account the need for one-semester pedagogical content knowledge, which is a key competence for future teachers. This practice must end, and the criteria for teachers' employment must be accepted and adhered to. Accredited preservice studies include general methodical and psychological preparation, as well as specific methodical courses, which are especially important for the natural sciences.

In North Macedonia, the admission of students to teaching faculties is not selective, and almost all applicants for initial teacher education programmes are accepted, which means that newly enrolled candidates have a range of academic knowledge and motivation. The interest in these studies is directly affected by the status of the teaching profession in the country. Therefore, policy-makers must find a mechanism to attract and select talented and 
motivated candidates for the teaching profession, and to further provide them with appropriate training in initial education, so they can develop the competencies required to be an effective teacher.

When it comes to in-service teachers, taking into account the recommendations regarding evaluation and assessment in education obtained from a recent analysis (OECD, 2019), substantial and consistent support to teachers through formative assessment and professional development resources is needed, as well as initiatives to reinforce the practical implementation of these measures. For this, it is necessary to overcome the systemic obstacles that prevent teachers from using the results of assessment to adapt their teaching to the needs and interests of the pupils. The main issues in this regard are the compact and inflexible curriculum and external inspections in schools in which the assessment is aimed at verifying the extent to which schools adhere to the curriculum. This discourages schools from adapting the curriculum to the specific context. Continuous professional development of teachers, mutual cooperation of all stakeholders in the educational process, and continuous support from the authorities and policymakers are of utmost importance (Watson et al., 2007; Wilson, 2000).

Vocational education reforms are of particular importance for the development of the economy in North Macedonia, because they will help companies to recruit professional staff among pupils during their secondary education. The final goal is to educate pupils who will be ready to enter the labour market after graduation.

Another problem that needs to be resolved in the near future is the adoption of a general strategy for working with gifted pupils, ensuring their support and motivation. At this point, very little has been done in this respect. Thus, there is no support for associations that organise competitions for pupils and prepare them for International Olympiads. The MON should finally find a solution and fully fund the associations for organising competitions, as well as covering the costs for preparation and participation in International Olympiads for pupils and leaders. An attempt has been made to improve the situation for both the pupils and associations involved in working with gifted pupils in the new Law on Primary Education (2019). Time will tell whether and how these legislative changes will be implemented in practice.

In general, the introduction of educational reforms, including those that concern teaching chemistry in primary, secondary and higher education, should be a strategic process that necessarily involves analysis, clearly set goals, systematic work and the involvement of all relevant stakeholders. Stronger interconnection between all levels of education is also needed, and special attention should be paid to preservice teacher education. 


\section{References}

Ardac, D., \& Akaygun, S. (2004). Effectiveness of multimedia-based instruction that emphasizes molecular representations on students' understanding of chemical change. Journal of Research in Science Teaching, 41(4), 317-337. doi:10.1002/tea.20005

Jašari, B. (Ed.). (2010). Употребата на компјутери и интернет во образовниот систем на РМ [The use of computers and the Internet in the education system of RM]. Skopje: Foundation Open Society Institute - Macedonia: Metamorphosis Foundation.

Barbour, M. K., \& Reeves, T.C. (2009). The reality of virtual schools: A review of the literature. Computers \& Education, 52(2), 402-416. doi:10.1016/j.compedu.2008.09.009

Carvalho-Knighton, K. M., \& Keen-Rocha, L. (2007). Using technology to enhance the effectiveness of general chemistry laboratory courses. Journal of Chemical Education, 84(4), 727-730. https://doi. org/10.1021/edo84p727

Centurino, V. A. S., \& Jones, L. R. (2017). TIMSS 2019 Science Framework. In I. V. S. Mullis, \&

M. O. Martin (Eds.), TIMSS 2019 assessment frameworks (pp. 27-55). Boston, MA: International Association for the Evaluation of Educational Achievement (IEA).

Đeladini, K., Stojanovski, T., Mitrevska, T. A., \& Andreevski, G. (2004). National report for development of education in the Republic of Macedonia for 2001-2004. Skopje: Ministry of Education and Science.

Demirdogen, B., \& Cakmakci, G. (2014). Investigating students' interest in chemistry through self-generated questions. Chemistry Education: Research and Practice, 15(2), 192-206. doi:10.1039/ $\mathrm{C}_{4} \mathrm{RPooO} 37 \mathrm{D}$

Doctoral School, Ss. Cyril and Methodius University in Skopje. (2008). Retrieved from http://www. ukim.edu.mk/doktorski_studii

European Commission. (2019). North Macedonia 2019 Report. Retrieved from https://ec.europa.eu/ neighbourhood-enlargement/sites/near/files/20190529-north-macedonia-report.pdf Geramitčioski, T., Velkovski, Z., Popovski, Z. T., Simovska, E., Murati, Đ., Adamčeska, S., ... Gjorgjijevski, T. (2004). Национална програма за развој на образованието во Република Македонија 2005-2015 [National programme for the development of education in Macedonia for 2005-2015]. Skopje: Ministry of Education and Science.

Manevska, M., \& Fotinovska, B. (Eds.) (2019). Ss. Cyril and Methodius University in Skopje, 1949-2019, 7o Years. Skopje: Birografika.

Metz, K. (1997). On the complex relation between cognitive development research and children's science curricula. Review of Educational Research, 67(1), 151-163. Retrieved from https://doi. org/10.3102/00346543067001151

Ministry of Education and Science. (2018, July 10). Отчет на Адеми: Образовни реформи по европски терк [The Ademi report: Educational reforms by European standards] [Press release]. Retrieved from http://mon.gov.mk/index.php/2014-07-23-14-03-24/vesti-i-nastani/2459-otchet-naademi-obrazovni-reformi-po-evropski-terk 
Organization for Economic Co-operation and Development - OECD. (2019). Преглед на ОЕЦД за евалуацијата и оценуването во образованието во Северна Македонија: Оценка и препораки [Review on evaluation and assessment in education in North Macedonia: Assessment and recommendations]. Skopje: UNICEF.

Report on the progress towards the millennium development goals Republic of Macedonia. (2009). Skopje: United Nations Development Program UNDP. Spasovska, M. (2017, June 29). Не сме подготвени за образование по Кембриџ [We are not ready for Cambridge education]. Radio Free Europe. Retrieved from https://www.slobodnaevropa. $\mathrm{mk} / \mathrm{a} / 28583555 \cdot \mathrm{html}$

Stojanovski, T., Andreevski, G., \& Spasovski, L. (1995). National report on education in for 1994-1996. (1995). Skopje: Ministry of Education and Physical Culture.

Trajkovska, B., Trajkovska, A., Salai, N., Atovska, S. M., Dimitrova, Lj., \& Murtezi, F. (2019).

Стратешки план 2019-2021 [Strategic plan 2019-2021]. Skopje: Ministry of Education and Science. Retrieved from http://mon.gov.mk/images/Florentin_MON/\%Do\%9o\%Do\%BD\%Do\%Bo\%D1\%81\% D1\%82\%Do\%Bo\%D1\%81\%Do\%B8\%D1\%98\%Do\%Bo/\%Do\%A1\%D1\%82\%D1\%80\%Do\%Bo\%D1\%82\% Do\%B5\%D1\%88\%Do\%BA\%Do\%B8_\%Do\%BF\%Do\%BB\%Do\%Bo\%Do\%BD_2019-2021_-_1.pdf Tytler, R. (2002). Teaching for understanding in science: Student conceptions research, and changing views of learning. Australian Science Teachers' Journal, 48(3), 14-21.

Vosniadou, S., Ioannides, C. P., Dimitrakopoulou, A., \& Papademetriou, E. (2001). Designing learning environments to promote conceptual change in science. Learning and Instruction, 11(4-5), 381-419. doi:10.1016/so959-4752(oo)0oo38-4

Watson, K., Steele, F., Vozzo, L., \& Aubusson, P. (2007). Changing in the subject: Retraining teachers to teach science. Research in Science Education, 37(2), 141-154. Retrieved from https://doi.org/10.1007/ s11165-006-9019-4

Wilson, C. (2000). Developing and disseminating teacher knowledge. Research in Science Education, 30(3), 301-316. Retrieved from https://doi.org/10.1007/BFo2461636

Анализа на гимназиското образование во нашата земја и во други земји на EУ [An analysis of gymnasium education in our country and other EU countries]. (2008). Skopje: Bureau for Development of Education.

Закон за високото образование [Law on Higher Education]. (2018). Skopje: Ministry of Education and Science. Retrieved from http://www.mon.gov.mk/images/documents/zakoni/ZAKON_

VISOKOTO_OBRAZOVANIE-final.pdf

Закон за основното образование [Law on Primary Education]. (2019). Skopje: Ministry of Education and Science. Retrieved from http://www.mon.gov.mk/images/Zakon_za_osnovnoto_ obrazovanie_br._161-_2019.pdf

Закон за средното образование [Law on Secondary Education]. (2017). Skopje: Ministry of Education and Science. Retrieved from http://www.mon.gov.mk/images/\%Do\%97\%Do\%Bo\%Do\%B A\%Do\%BE\%Do\%BD_\%Do\%B7\%Do\%Bo_\%D1\%81\%D1\%80\%Do\%B5\%Do\%B4\%Do\%BD\%Do\%BE\% D1\%82\%Do\%BE_\%Do\%BE\%Do\%B1\%D1\%80\%Do\%Bo\%Do\%B7\%Do\%BE\%Do\%B2\%Do\%Bo\%Do\% 
BD\%Do\%B8\%Do\%B5_\%Do\%BF\%D1\%80\%Do\%B5\%D1\%87\%Do\%B8\%D1\%81\%D1\%82\%Do\%B5\%Do \%BD_1.pdf

Концепција за деветгодишното основно воспитание и образование [The concept for nine-year primary upbringing and education]. (2007). Skopje: Ministry of Education and Science. Retrieved from https://www.bro.gov.mk/wp-content/uploads/2019/o5/Koncepcija-za-devetgodisno-osnovnovospitanie-i-obrazovanie.pdf

Стратегија за образованието за 2018-2015 година и Акциски план [Strategic plan on education 2018-2025 and Action plan]. (2018). Skopje: Ministry of Education and Science. Retrieved from http://mrk.mk/wp-content/uploads/2018/10/Strategija-za-obrazovanie-MAK-WEB.pdf

\section{Biographical note}

Marina Stojanovska, $\mathrm{PhD}$, is an associate professor in the field of chemistry education at the Faculty of Natural Sciences and Mathematics, Ss. Cyril and Methodius University, Skopje. Her research focuses on new strategies for improving chemistry teaching, alternative conceptions in chemistry, learning chemistry at all three levels of chemical concepts, assessment, gamebased learning, experiments in chemistry teaching, and others. For more than 10 years, she has been involved in the professional development of pre- and in-service chemistry teachers during their pedagogical training or as a part of their life-long learning.

IvANKA MiJić, M.Sc., is an advisor for teaching chemistry at the Bureau for Development of Education at the Ministry of Education and Science in North Macedonia. Her work is focused on creating educational standards and chemistry curricula for primary and secondary education, as well as professional advisory work with teachers and teacher training. Her background includes working experience as a high school chemistry teacher, as well as participation in many workshops, seminars, conferences, trainings and projects.

Vladimir M. Petruševski, PhD, is a full professor of physical chemistry and of chemistry education at the Faculty of Natural Sciences and Mathematics, Ss. Cyril and Methodius University, Skopje. His research interests comprise experiments in chemistry teaching, demonstrations, models, analogies, and animations. Fields of expertise: molecular spectroscopy (IR and Raman methods) and structural chemistry. He is involved in the organization of national chemistry competitions and international olympiads and in the organization of chemistry spectacles. 